\title{
Evaluasi Performa Karkas Kelinci Lokal dan New Zealand White Jantan pada Berat Potong yang Berbeda
}

\author{
Carcass Performance Evaluation of Local and New Zealand White Bucks \\ from Different Slaughter Weight
}

\author{
T. Wahyono ${ }^{*}$, Sadarman ${ }^{2}$, T. Handayani ${ }^{1}$, A.C. Trinugraha ${ }^{1}$, \& D. Priyoatmojo ${ }^{1}$ \\ ${ }^{1}$ Bidang Pertanian, Pusat Aplikasi Isotop dan Radiasi, Badan Tenaga Nuklir Nasional \\ JL. Lebak Bulus Raya No. 49 Cilandak Jakarta Selatan 12440 \\ 2Program Studi Peternakan, Fakultas Pertanian dan Peternakan, UIN Sultan Syarif Kasim \\ JL. HR. Soebrantas KM. 15 Simpang Baru Panam Pekanbaru \\ *Email korespondensi: teguhwahyono@batan.go.id
}

\author{
- Diterima: 27 November 2020 • Direvisi: 09 Januari 2021 • Disetujui: 14 Januari 2021
}

\begin{abstract}
ABSTRAK. Penelitian ini bertujuan untuk mengevaluasi performa karkas kelinci jantan yang dipotong pada bangsa dan kategori berat potong yang berbeda. Rancangan Acak Lengkap (RAL) pola faktorial digunakan, dimana bangsa kelinci (lokal dan New Zealand White) dan kategori berat potong ( $<2 \mathrm{~kg}$ dan $>2 \mathrm{~kg}$ ) sebagai faktor-faktornya. Jumlah ulangan pada setiap pengelompokan adalah 15 ekor sehingga total 60 ekor kelinci digunakan. Peubah yang diamati adalah berat karkas, berat daging, berat tulang, persentase karkas, persentase daging, persentase tulang dan meat bone ratio (MBR). Dalam penelitian ini juga dilakukan pengamatan korelasi antara berat potong dan berat karkas dengan berat karkas, berat daging, berat tulang, persentase karkas, persentase daging, persentase tulang dan MBR. Hasil penelitian menunjukkan bahwa perbedaan bangsa dan berat potong memberikan perbedaan signifikan terhadap berat karkas, daging, dan tulang $(\mathrm{P}<0,05)$. Berat potong berkorelasi positif dengan berat karkas $(\mathrm{r}=0,955 ; \mathrm{P}<0,01)$. Perbedaan bangsa dan berat potong tidak berpengaruh signifikan terhadap persentase karkas dimana karkas kelinci lokal pada kisaran 53,04\%, sedangkan New Zealand White 51,66\%. Tidak terdapat perbedaan signifikan antara MBR di kedua kelompok dengan kategori berat $>2 \mathrm{~kg}$. Kelinci New Zealand White berat $<2 \mathrm{~kg}$ menghasilkan MBR yang terendah yaitu sebesar 2,17 $(\mathrm{P}<0,05)$. Terdapat interaksi yang sangat nyata $(\mathrm{P}<0,01)$ antara faktor perbedaan bangsa dengan berat potong terhadap berat karkas, persentase karkas dan berat daging. Kesimpulan dari penelitian ini adalah bahwa kelinci lokal dengan berat potong $<2 \mathrm{~kg}$ dan $>2 \mathrm{~kg}$ menghasilkan persentase karkas dan MBR yang berbeda tidak nyata $(\mathrm{P}>0,05)$. Kelinci New Zealand White sebaiknya dipotong pada berat $>2 \mathrm{~kg}$ karena pada berat potong $<2 \mathrm{~kg}$ menghasilkan rasio MBR yang rendah. Terdapat interaksi antara berat potong dan perbedaan bangsa terhadap performa karkas kelinci jantan.
\end{abstract}

Kata kunci: Karkas; kelinci jantan; kelinci lokal; new zealand white

ABSTRACT. This study investigated the performance of Local and New Zealand White buck carcass at different weights. A factorial completely randomized design was applied, with rabbit breeds (local and New Zealand White) and weight category (<2 kg and >2 kg) as factors. 60 bucks were used divided into 15 bucks per group. Carcass weight, meat weight, bone weight, carcass percentage, meat percentage, bone percentage, meat bone ratio (MBR) were observed. Correlation between slaughter and carcass weight with carcass weight, meat weight, bone weight carcass percentage, meat percentage, bone percentage and MBR also observed in this study. Results showed that the differences in breeds and slaughtering weight gave significant differences in carcass, meat, and bone weight $(P<0.05)$. Slaughtering weight was positively correlated with carcass weight $\left(R^{2}=0.955 ; P<0.01\right)$. Breed and slaughtering weight category differences did not significantly affect carcass percentage, where local rabbit carcass was $53.04 \%$, while New Zealand White was $51.66 \%$. There was no significant difference between MBR in the two groups with weight $>2 \mathrm{~kg}$. New Zealand White rabbits in $<2 \mathrm{~kg}$ weight categories produced the lowest MBR by $2.17(P<0.05)$. Significant interaction $(P<0.01)$ between different breed and weight categories was reported on carcass weight, carcass percentage, and meat weight. In conclusion, there are no differences in carcass percentage and MBR ratio between two rabbit breeds with $<2 \mathrm{~kg}$ weight categories. New Zealand White rabbits should be slaughtered at $>2 \mathrm{~kg}$ weight categories due to the lower $M B R$ ratio on $<2 \mathrm{~kg}$ weight categories. The current study reported that there was an interaction between different breed and weight categories on carcass performance.

Keywords: Bucks, carcass, local rabbit, new zealand white 


\section{PENDAHULUAN}

Perubahan pola pikir masyarakat saat ini telah membuka peluang bagi usaha peternakan sumber protein alternatif seperti kelinci. Peningkatan ketertarikan terhadap daging kelinci berasal dari kelompok konsumen yang semakin sadar akan kesehatan pangan dan utilisasi nutrisi di dalamnya (Culerre \& Zotte, 2018). Daging kelinci memiliki nilai nutrisi yang tinggi dan dapat dikategorikan sebagai sumber pangan fungsional (Priyanti \& Raharjo, 2012). Kelinci dikenal masyarakat luas sebagai ternak yang menghasilkan daging tinggi protein dan rendah lemak. Pangsa pasar kelinci relatif stabil sehingga prospeknya cenderung meningkat dengan stabil. Populasi kelinci pada tahun 2018 di Indonesia mencapai 1.251 .000 ekor dengan peningkatan sebesar 13,42\% dari tahun 2015 (Kementerian Pertanian, 2018). Jawa Timur dan Jawa Tengah adalah dua provinsi yang menjadi basis populasi kelinci terbesar di Indonesia. Berdasarkan pengamatan di lapangan, bangsa kelinci lokal dan New Zealand White adalah dua bangsa yang dominan digunakan sebagai sumber penghasil daging.

Kelinci lokal memiliki kelebihan dalam menghasilkan daging yang berkualitas baik yaitu kaya protein dan rendah lemak (Belabbas et al., 2019). Lebih lanjut dijelaskan bahwa kelinci lokal telah memiliki adaptasi yang baik terhadap iklim dan pakan lokal yang tersedia. Brahmantiyo et al. (2014) melaporkan bahwa kelinci lokal yang dipotong sebagai penghasil daging merupakan kelinci yang sudah tidak bereproduksi ataupun sakit. Kelinci New Zealand White adalah bangsa kelinci yang berasal dari Amerika Serikat dengan karakteristik fisik bulu putih, padat, dan memiliki mata merah. Bangsa kelinci New Zealand White cocok dibudidayakan sebagai penghasil daging komersial karena pertumbuhannya yang cukup cepat (Marhaeniyanto et al., 2015). Brahmantiyo et al. (2017) juga melaporkan kelinci New Zealand White relatif sudah adaptif di lingkungan tropis Indonesia. Kelinci jantan lebih diprioritaskan sebagai kelinci pedaging karena memiliki laju pertumbuhan yang lebih cepat dibandingkan betina (Haryoko \& Warsiti, 2008). Selain itu, kelinci betina lebih diprioritaskan sebagai bakalan indukan daripada sebagai bakalan potong. Al-Dobaib (2010) dan Tůmová et al. (2014) menjelaskan karakeristik karkas dan daging sangat dipengaruhi oleh perbedaan bangsa kelinci.

Selain variasi bangsa, perbedaan kategori berat potong juga dapat berpengaruh terhadap produksi karkas dan daging yang dihasilkan. Variasi berat kelinci yang dipotong berkisar 1,5$3 \mathrm{~kg}$. Hal tersebut berpengaruh terhadap variasi produksi karkas dan daging yang dihasilkan. Karakteristik karkas dan daging kelinci berasosiasi dengan perbedaan kategori ukuran tubuh kelinci ketika dipotong (Tůmová et al., 2014). Wibowo et al. (2014) menjelaskan besarnya produksi daging dapat diestimasi dari besarnya produksi karkas. Mu'tazi et al. (2019) melaporkan terdapat hubungan antara berat potong, karkas, daging, dan tulang yang dihasilkan oleh ternak. Belum banyak informasi terkait pengaruh perbedaan bangsa dan berat potong terhadap produksi karkas, daging dan tulang di Indonesia. Berdasarkan hal tersebut, penelitian ini bertujuan untuk mengevaluasi performa karkas kelinci jantan yang dipotong pada bangsa dan kategori berat potong yang berbeda. Hipotesa dari penelitian ini adalah: perbedaan bangsa dan kategori berat potong akan memengaruhi performa karkas kelinci jantan. Penelitian ini juga bermanfaat untuk memberikan rekomendasi kepada pelaku industri peternakan kelinci. Rekomendasi yang dimaksud adalah informasi bangsa dan berat potong kelinci jantan yang tepat untuk menghasilkan perolehan karkas yang optimal.

\section{MATERI DAN METODE}

\section{Bahan Penelitian}

Sebanyak 60 ekor kelinci jantan diperoleh dari peternak dan pasar hewan di wilayah Kabupaten Sleman, Daerah Istimewa Yogyakarta serta Kabupaten Magelang, Jawa Tengah. Pengelompokan ternak kemudian dipisahkan berdasarkan kategori berat potong $(<2 \mathrm{~kg}$ dan $>2 \mathrm{~kg}$ ) dan bangsa kelinci (lokal dan New Zealand White), sehingga masing-masing kelompok perlakuan berjumlah 15 ekor. Berdasarkan informasi yang diperoleh, ransum yang diberikan sebelum kelinci diperjual belikan adalah kombinasi rumput lapangan, 
kangkung, jerami kacang tanah, dedak, bekatul dan konsentrat komersial dalam komposisi yang bervariasi.

\section{Rancangan Percobaan dan Peubah yang Diamati}

Rancangan yang digunakan dalam penelitian ini adalah Rancangan Acak Lengkap (RAL) pola faktorial, dimana bangsa kelinci (lokal dan New Zealand White) dan kategori berat potong ( $<2 \mathrm{~kg}$ dan $>2 \mathrm{~kg}$ ) sebagai faktorfaktornya. Ulangan untuk masing-masing perlakuan sebanyak 15 ekor. Peubah yang diamati adalah berat karkas, berat daging, berat tulang, persentase karkas dan meat bone ratio (MBR).

Sebelum penyembelihan, kelinci dipuasakan terlebih dahulu selama 12 jam. Air minum tetap diberikan secara adlibitum. Penyembelihan dilakukan dengan memotong saluran trakhea, esophagus, arteri karotis dan vena jugularis. Proses bleeding (pengeluaran darah) dilakukan secara sempurna kemudian kepala dan ekor dipisahkan dari tubuh kelinci.

Setelah proses penyembelihan, pengambilan sampel karkas terhadap 60 ekor kelinci kemudian dilakukan berdasarkan metode dalam Brahmantiyo et al. (2017). Irisan dilakukan antara tulang dan bagian tendo sendi kedua kaki belakang kemudian digantungkan secara vertikal. Kaki depan dan belakang juga dipisahkan dari tubuh kelinci dengan memotong pada bagian siku. Pengulitan dilakukan dengan melepaskan seluruh bagian kulit dari tubuh kelinci. Pengeluaran organ dalam berupa saluran pencernaan, hati, jantung, ginjal dan paru-paru dilakukan dari rongga dada serta perut (evisceration).

Karkas yang diperoleh ditimbang kemudian dilakukan proses pemisahan daging dan tulang (deboning). Setiap bagian daging dan tulang ditimbang terpisah. Persentase karkas diperoleh dengan membandingkan berat karkas dengan berat hidup dalam satuan persen. Persentase daging dan tulang dilakukan dengan membandingkan berat daging atau tulang dengan berat karkas dalam satuan persen. Kalkulasi MBR diperoleh dengan rumus:

$$
\mathrm{MBR}=\frac{\text { Berat daging }(\mathrm{g})}{\text { Berat tulang }(\mathrm{g})}
$$

\section{Analisis Statistik}

Data yang diperoleh dianalisis keragamannya dengan anova. Uji lanjut Duncan Multiple Range Test (DMRT) dilakukan apabila dalam setiap kelompok perlakuan terdapat perbedaan yang nyata (Steel \& Torrie, 1960). Analisis korelasi juga dilakukan terhadap berat potong dan berat karkas dengan peubah yang lain. Analisis data menggunakan software statistik SPSS versi 22.0.

\section{HASIL DAN PEMBAHASAN}

\section{Berat Karkas, Daging dan Tulang}

Berat karkas, daging dan tulang yang diperoleh dalam penelitian ini dapat dilihat pada Tabel 1. Kelinci jantan New Zealand White dengan berat potong $>2 \mathrm{~kg}$ menghasilkan berat karkas, daging dan tulang tertinggi $(P<0,05)$. Berdasarkan uji statistik, perbedaan bangsa dan berat potong memberikan perbedaan yang signifikan $(\mathrm{P}<0,05)$ terhadap berat karkas, daging dan tulang kelinci jantan. Terdapat interaksi yang nyata $(\mathrm{P}<0,05)$ antara bangsa kelinci dan berat potong yang memengaruhi berat karkas, daging dan tulang kelinci jantan. Korelasi antara berat potong dengan performa karkas juga dapat dilihat pada Tabel 2. Berat potong berkorelasi positif dengan berat karkas $(\mathrm{r}=0,955 ; \mathrm{P}<0,01)$, daging $(\mathrm{r}=0,846 ; \mathrm{P}<0,01)$ dan tulang $(\mathrm{r}=0,955 ; \mathrm{P}<0,01)$. Berat karkas juga berkorelasi positif dengan berat daging $(\mathrm{r}=0,808 ; \mathrm{P}<0,01)$ dan tulang $(\mathrm{r}=0,983 ; \mathrm{P}<0,01)$.

Definisi karkas kelinci adalah bagian dari tubuh kelinci setelah dipotong dan dikurangi dengan darah, kepala, kulit, kaki, ekor, saluran pencernaan serta isi rongga dada (Brahmantiyo et al., 2017). Sebagai informasi, definisi karkas yang umum di Indonesia adalah sesuai standar Amerika Serikat yaitu kepala dan kaki bukan bagian dari karkas. Standar Eropa menyatakan kepala dan kaki adalah bagian dari karkas kelinci (Belabbas et al., 2019). Berat karkas merupakan faktor penting karena berpengaruh terhadap nilai ekonomis dari ternak kelinci (Royadi \& Malik, 2016). Hasil penelitian didapatkan berat potong yang tinggi akan 
menghasilkan berat karkas, daging dan tulang yang lebih tinggi. Bangsa kelinci New Zealand White juga cenderung menghasilkan performa karkas yang lebih tinggi dibandingkan kelinci lokal. Kelinci New Zealand White memiliki performa pertumbuhan yang cepat sehingga cocok digunakan sebagai kelinci pedaging (Marhaeniyanto et al., 2015). Akan tetapi, variabel yang lebih tepat dalam menggambarkan performa karkas adalah persentase karkas dan MBR yang akan dibahas pada sub bab persentase karkas dan MBR. Berat potong berasosiasi positif terhadap penimbunan lemak tubuh, persentase karkas dan kualitas daging kelinci (Brahmantiyo et al.,
2017; Wibowo et al., 2014). Zotte et al. (2015) menjelaskan berat karkas sesuai dengan berat potong kelinci ketika dipotong. Peningkatan berat potong akan diikuti oleh peningkatan berat dan komponen karkas (Haryoko \& Warsiti, 2008). Perbandingan berat karkas kelinci yang berdasar pada variabel berat potong lebih dianggap bermanfaat secara komersial dibandingkan berdasar perbedaan fase pertumbuhan dan genetik (Blasco et al., 2018). Hal tersebut karena masih terdapat selisih harga antara kelinci lokal dan New Zealand White yang akan berpengaruh secara komersial.

Tabel 1. Berat karkas, daging, tulang dan meat bone ratio kelinci jantan pada bangsa dan berat potong yang berbeda.

\begin{tabular}{|c|c|c|c|}
\hline \multirow{2}{*}{ Bangsa kelinci } & \multicolumn{2}{|c|}{ Kategori berat potong } & \multirow{2}{*}{ Rerata } \\
\hline & $<2 \mathrm{~kg}$ & $>2 \mathrm{~kg}$ & \\
\hline \multicolumn{4}{|l|}{ Berat Karkas } \\
\hline Lokal & $941,77 \pm 92,24^{\mathrm{a}}$ & $1096,00 \pm 83,98^{b}$ & $1018,88 \pm 88,11^{\mathrm{a}}$ \\
\hline New Zealand White & $937,05 \pm 62,94^{\mathrm{a}}$ & $1313,48 \pm 243,27 \mathrm{c}$ & $1125,27 \pm 153,11^{\mathrm{b}}$ \\
\hline Rerata & $939,41 \pm 77,59^{a}$ & $1204,74 \pm 163,63^{b}$ & \\
\hline \multicolumn{4}{|l|}{ Berat Daging } \\
\hline Lokal & $666,83 \pm 79,42^{\mathrm{a}}$ & $781,73 \pm 86,97 \mathrm{~b}$ & $724,28 \pm 83,20^{a}$ \\
\hline New Zealand White & $639,25 \pm 61,01^{\mathrm{a}}$ & $943,92 \pm 195,91^{c}$ & $791,58 \pm 128,46^{b}$ \\
\hline Rerata & $653,04 \pm 70,22^{\mathrm{a}}$ & $862,82 \pm 141,44^{\mathrm{b}}$ & \\
\hline \multicolumn{4}{|l|}{ Berat Tulang } \\
\hline Lokal & $274,93 \pm 35,59^{a}$ & $314,33 \pm 31,30^{\mathrm{b}}$ & $294,63 \pm 35,45^{\mathrm{a}}$ \\
\hline New Zealand White & $297,81 \pm 28,54^{\mathrm{ab}}$ & $369,56 \pm 53,77 c$ & $333,68 \pm 41,16^{b}$ \\
\hline Rerata & $286,37 \pm 34,07^{a}$ & $341,94 \pm 42,54^{\mathrm{b}}$ & \\
\hline \multicolumn{4}{|l|}{ Meat Bone Ratio } \\
\hline Lokal & $2,46 \pm 0,35^{b}$ & $2,52 \pm 0,42^{b}$ & $2,49 \pm 0,39$ \\
\hline New Zealand White & $2,17 \pm 0,30^{\mathrm{a}}$ & $2,55 \pm 0,31^{b}$ & $2,36 \pm 0,31$ \\
\hline Rerata & $2,31 \pm 0,33^{\mathrm{a}}$ & $2,53 \pm 0,37^{b}$ & \\
\hline
\end{tabular}

Keterangan : superskrip yang berbeda pada baris yang sama menunjukkan perbedaan yang nyata $(\mathrm{P}<0,05)$.

Tingginya berat daging dan tulang kelinci jantan New Zealand White pada berat potong $>2$ $\mathrm{kg}$ berasosiasi positif dengan tingginya berat karkas (Tabel 1). Hal tersebut diperkuat dengan tingginya korelasi antara berat karkas dengan berat daging dan tulang (Tabel 2). Mu'tazi et al. (2019) menyatakan berat daging dan lemak cenderung meningkat seiring dengan peningkatan berat karkas, namun tidak demikian pada tulang. Berat karkas akan meningkatkan berat potongan komersialnya, diantaranya adalah berat daging (Brahmantiyo et al., 2017). Berat tulang yang tinggi dapat diasosiasikan dengan berat potong kelinci (Zotte et al., 2015). Lebih lanjut dijelaskan pertumbuhan tulang lebih dipengaruhi oleh sistem pemeliharaan kelinci. Informasi berat tulang yang dihasilkan dari karkas kelinci, cukup penting bagi para pelaku industri kuliner. Hal tersebut karena tulang kelinci juga dapat dimanfaatkan sebagai bahan baku kuliner alih-alih dipandang sebagai limbah karkas. Perbedaan performa karkas diduga dapat disebabkan oleh perbedaan manajemen kandang selama pemeliharaan kelinci. Kelinci yang dipelihara dalam kandang individu akan 
menghasilkan variabel-variabel karkas yang lebih tinggi dibandingkan kelinci dalam kandang komunal (Lazzaroni et al., 2009). Zotte et al. (2015) melaporkan perbedaan genetik, sistem pemeliharaan dan pakan adalah faktor penting yang membedakan performa karkas kelinci.

Tabel 2. Matriks korelasi (r) antara berat potong dan berat karkas dengan peubah pemotongan yang lain $(n=60)$

\begin{tabular}{lcc}
\hline & Berat potong & Berat karkas \\
\hline Berat potong & - & $0,955^{* *}$ \\
Berat karkas & $0,955^{* *}$ & - \\
Persentase karkas & $0,104^{\text {tn }}$ & $0,394^{* *}$ \\
Berat daging & $0,846^{* *}$ & $0,808^{* *}$ \\
Persentase daging & $0,292^{*}$ & $0,426^{* *}$ \\
Berat tulang & $0,915^{* *}$ & $0,983^{* *}$ \\
Persentase tulang & $-0,292^{*}$ & $-0,426^{* *}$ \\
Meat Bone Ratio & $0,304^{*}$ & $0,445^{* *}$ \\
\hline
\end{tabular}

Keterangan: $\mathrm{tn}=$ tidak nyata; ${ }^{*}=$ berbeda nyata $(\mathrm{P}<0,05) ;{ }^{* *}=$ berbeda sangat nyata $(\mathrm{P}<0,01)$.

\section{Persentase Karkas dan Meat Bone Ratio}

Perhitungan persentase karkas hasil penelitian ini dapat dilihat pada Tabel 3. Persentase karkas kelinci lokal berada pada kisaran 53,04\% namun tidak berbeda secara signifikan dengan New Zealand White (51,66\%). Rerata persentase karkas kelinci jantan dengan berat potong $<2 \mathrm{~kg}$ bahkan hampir identik dengan berat potong $>2 \mathrm{~kg}(52,30$ vs $52,40 \%)$. Hasil analisis statistik menunjukkan perbedaan bangsa dan berat potong tidak berpengaruh signifikan $(\mathrm{P}>0,05)$ terhadap persentase karkas. Akan tetapi, terdapat interaksi yang nyata $(\mathrm{P}<0,05)$ antara kedua faktor tersebut. Hasil analisis statistik menunjukkan perbedaan bangsa kelinci tidak berpengaruh signifikan terhadap persentase tulang dan daging. Nilai persentase daging dipengaruhi oleh perbedaan berat potong $(\mathrm{P}<0,05)$. Persentase daging tertinggi dihasilkan oleh kelinci jantan dengan berat potong $>2 \mathrm{~kg}(71,39 \%, \mathrm{P}<0,05)$. Berat karkas berkorelasi positif dengan persentase karkas dan daging, namun berkorelasi negatif dengan persentase tulang (Tabel 2). Pada Tabel 1 juga menunjukkan tidak terdapat perbedaan yang signifikan antara MBR kelinci lokal berat $<2 \mathrm{~kg},>2 \mathrm{~kg}$ dan New Zealand White berat $>2 \mathrm{~kg}$. Kelinci New Zealand White berat $<2 \mathrm{~kg}$ menghasilkan MBR yang terendah sebesar 2,17 $(\mathrm{P}<0,05)$.

Tabel 3. Persentase karkas, daging dan tulang kelinci jantan pada bangsa dan berat potong yang berbeda

\begin{tabular}{|c|c|c|c|}
\hline \multirow{2}{*}{ Bangsa kelinci } & \multicolumn{2}{|c|}{ Kategori berat potong } & \multirow{2}{*}{ Rerata } \\
\hline & $<2 \mathrm{~kg}$ & $>2 \mathrm{~kg}$ & \\
\hline \multicolumn{4}{|l|}{$\%$ Karkas } \\
\hline Lokal & $54,04 \pm 1,59$ & $52,04 \pm 3,35$ & $53,04 \pm 2,47$ \\
\hline New Zealand White & $50,57 \pm 3,10$ & $52,75 \pm 2,78$ & $51,66 \pm 2,94$ \\
\hline Rerata & $52,30 \pm 2,34$ & $52,40 \pm 2,41$ & \\
\hline \multicolumn{4}{|l|}{$\%$ Daging } \\
\hline Lokal & $70,76 \pm 3,62$ & $71,18 \pm 3,48$ & $70,97 \pm 3,55$ \\
\hline New Zealand White & $68,15 \pm 3,21$ & $71,61 \pm 2,41$ & $69,88 \pm 2,81$ \\
\hline Rerata & $69,45 \pm 3,41^{\mathrm{b}}$ & $71,39 \pm 2,94^{\mathrm{a}}$ & \\
\hline \multicolumn{4}{|l|}{$\%$ Tulang } \\
\hline Lokal & $29,24 \pm 3,62$ & $28,83 \pm 3,48$ & $29,03 \pm 3,55$ \\
\hline New Zealand White & $31,85 \pm 3,21$ & $28,39 \pm 2,41$ & $30,12 \pm 2,81$ \\
\hline Rerata & $30,55 \pm 3,41^{\mathrm{b}}$ & $28,61 \pm 2,94^{\mathrm{a}}$ & \\
\hline
\end{tabular}

Keterangan: superskrip yang berbeda pada baris yang sama menunjukkan perbedaan yang nyata $(\mathrm{P}<0,05)$ 
Persentase karkas adalah variabel yang penting dalam menentukan performa karkas kelinci yang dihasilkan. Semakin tinggi nilai persentase karkas menginterpretasikan nilai ekonomis ternak kelinci. Berdasarkan informasi dari beberapa literatur, persentase karkas yang diperoleh dalam penelitian ini berada pada kisaran nilai normal. Kelinci lokal dengan berat potong $<2 \mathrm{~kg}$ menghasilkan persentase karkas sebesar 44,51-50,92\% (Royadi \& Malik, 2016). Hassan et al. (2011) melaporkan persentase karkas kelinci New Zealand White dengan berat potong $2 \mathrm{~kg}$ adalah 59\%. Kelinci New Zealand White yang memiliki berat potong $<2 \mathrm{~kg}$ menghasilkan persentase karkas sebesar 51,27\% (Nasr et al., 2017) dan 48,16\% (Wibowo et al., 2014). Kelinci New Zealand White dengan berat $<2 \mathrm{~kg}$ menghasilkan persentase karkas 48,98 $54,70 \%$, sedangkan berat potong $>2 \mathrm{~kg}$ menghasilkan persentase 58,04 - 58,72\% (Haryoko \& Warsiti, 2008). Pada umur siap potong (>90 hari), kelinci New Zealand White dengan berat $>3 \mathrm{~kg}$ dapat menghasilkan persentase karkas sebesar 55,80\% (Brahmantiyo et al., 2017). Kelinci golongan besar (>3 kg) dapat menghasilkan karkas yang lebih tinggi yaitu minimal 58,4\% (Lazzaroni et al., 2009).

Nilai persentase karkas yang tidak dipengaruhi oleh perbedaan bangsa diduga disebabkan oleh variabel umur yang tidak seragam. Dalam penelitian ini, umur kelinci yang digunakan bervariasi dari 2-10 bulan. Kelinci lokal adalah kategori kelinci kecilsedang, sedangkan New Zealand White adalah kelinci besar. Hal tersebut akan berpengaruh terhadap perbedaan berat hidup dalam kategori umur yang sama. Hal yang sama dilaporkan oleh Al-Dobaib (2010) yang menjelaskan terdapat berbagai inkonsistensi dalam membahas perbedaan persentase karkas antar bangsa kelinci. Hal tersebut disebabkan oleh adanya faktor perbedaan variasi berat, umur potong dan genetik individual antar komponen bangsa. Wibowo et al. (2014) menjelaskan persentase karkas lebih dipengaruhi oleh berat karkas dan berat hidup. Hasil yang kontradiktif dilaporkan oleh Tůmová et al. (2014) yang menyatakan pebedaan bangsa kelinci dapat memengaruhi berat, persentase dan komposisi karkas. Perbandingan data penelitian ini dengan beberapa literatur dibatasi oleh perbedaan variabel yang digunakan. Dalam penelitian ini, evaluasi dilakukan pada bangsa dan berat potong yang berbeda. Dalam beberapa literatur, variabel perbedaan diamati pada umur yang sama. Dalam beberapa kasus, faktor pemuasaan ternak sebelum dipotong juga berasosiasi dengan persentase karkas (Nasr et al., 2017).

Rasio MBR merupakan indikator yang cukup penting untuk menentukan performa karkas karena dapat digunakan sebagai pertimbangan pelaku industri dalam mengolah karkas kelinci. Meat bone ratio adalah rasio antara produksi daging dan tulang. Angka tersebut merupakan pembanding untuk mengetahui jumlah daging yang dihasilkan daripada tulang (Mu'tazi et al., 2019). Pada kategori berat potong $<2 \mathrm{~kg}$, kelinci lokal menghasilkan nilai MBR yang lebih tinggi dibandingkan New Zealand White. Hal tersebut diduga disebabkan oleh faktor umur yang berbeda pada kedua bangsa tersebut. Pada berat potong sekitar $2 \mathrm{~kg}$, kelinci lokal sudah dalam masa dewasa sehingga pertumbuhan tulang cenderung berbenti. Pada bangsa New Zealand White, pertumbuhan tulang masih berlangsung karena pada berat potong $2 \mathrm{~kg}$ karena masih tergolong dalam umur muda. Brahmantiyo et al. (2017) menjelaskan perbedaan genetik dalam mencapai umur dewasa akan memengaruhi persentase beberapa bagian tubuh. Dalam konteksi ini adalah persentase daging dan tulang. Marhaeniyanto et al. (2015) melaporkan berat kelinci New Zealand White pada umur 58 hari (anakan) dapat mencapai 1,8 kg.

Faktor kedewasaan umur kelinci merupakan faktor utama yang memengaruhi tingginya rasio MBR. Perkembangan tulang berpengaruh terhadap ukuran tubuh dan persentase daging seekor kelinci (Brahmantiyo et al., 2017). Blasco et al. (2018) melaporkan ternak yang lebih muda akan menghasilkan proporsi tulang yang tinggi. Kecepatan tumbuh komponen tubuh ternak saling beriringan mulai dari pertumbuhan tulang, disusul oleh otot dan lemak (Mu'tazi et al., 2019). Tůmová et al. (2014) melaporkan komposisi tubuh kelinci mulai cenderung stabil setelah berumur 91 hari. Bangsa dengan berat dewasa yang rendah memiliki konsekuensi akan dijadikan kelinci 
potong pada umur tua (Blasco et al., 2018). Hal tersebut direpresentasikan pada nilai MBR kelinci lokal yang lebih tinggi dibandingkan New Zealand White pada kategori potong $<2 \mathrm{~kg}$.

Rasio MBR kelinci New Zealand White dalam penelitian ini berada pada kisaran 2,172,55 dan sesuai dengan penelitian sebelumnya. Pada penelitian Wibowo et al. (2014), rasio MBR yang dihasilkan kelinci New Zealand White berkisar 2,30-2,88. Pada umur yang lebih dewasa (berat potong $>3 \mathrm{~kg}$ ), kelinci New Zealand White dapat menghasilkan MBR 5,825,96 (Brahmantiyo et al., 2017). Al-Dobaib (2010) melaporkan rasio MBR kelinci lokal Arab Saudi berkisar 3,44-3,66. Tidak banyak studi yang menginvestigasi pengaruh bangsa kelinci terhadap rasio MBR. Tidak terdapat perbedaan MBR pada beberapa bangsa kelinci yang dipilih secara acak pada umur 63 hari (Zotte et al., 2015).

\section{Hubungan Regresi Berat Potong dan Berat Karkas}

Berdasarkan hubungan regresi antara berat potong dan berat karkas, rumus pendugaan berat karkas berdasarkan bangsa kelinci telah diperoleh (Gambar 1 dan 2). Berat karkas (y) kelinci jantan lokal dan New Zealand White pada berat potong $(\mathrm{x})$ dapat diperoleh dengan rumus:

$$
\begin{aligned}
\mathrm{y}= & 0,465 \mathrm{x}+124,05(\mathrm{r}=0,779 ; \mathrm{n}=30 ; \text { kelinci } \\
& \text { lokal }) \\
\mathrm{y}= & 0,607 \mathrm{x}-190,59(\mathrm{r}=0,949 ; \mathrm{n}=30 ; \text { kelinci } \\
& \text { New Zealand White })
\end{aligned}
$$

Berdasarkan kategori berat potong, hubungan berat karkas (y) dan berat potong (x) kelinci jantan telah ditampilkan pada Gambar 3 dan 4 dengan rumus estimasi:

$$
\begin{aligned}
\mathrm{y}= & 0,422 \mathrm{x}+180,95(\mathrm{r}=0,518 ; \mathrm{n}=30 ; \text { berat } \\
& \text { potong }<2 \mathrm{~kg}) \\
\mathrm{y}= & 0,608 \mathrm{x}-188,78(\mathrm{r}=0,906 ; \mathrm{n}=30 ; \text { berat } \\
& \text { potong }>2 \mathrm{~kg})
\end{aligned}
$$

Berat badan adalah parameter yang dapat digunakan untuk menentukan berat karkas yang dihasilkan oleh ternak sehingga akurasinya sangat diharapkan (Suliani et al., 2017). Nilai korelasi dari kalkulasi berat karkas pada kelinci lokal dan New Zealand White termasuk tinggi sehingga dapat di implementasikan dalam mengestimasi berdasarkan berat potong kelinci. Dalam perspektif lain, rumus pendugaan juga dapat diterapkan dalam seleksi bibit ternak yang baik (Suliani et al., 2017). Blasco et al. (2018) melaporkan perlu jumlah sampel yang lebih besar untuk menentukan estimasi berat karkas berdasarkan perbedaan genetik kelinci agar lebih presisi.

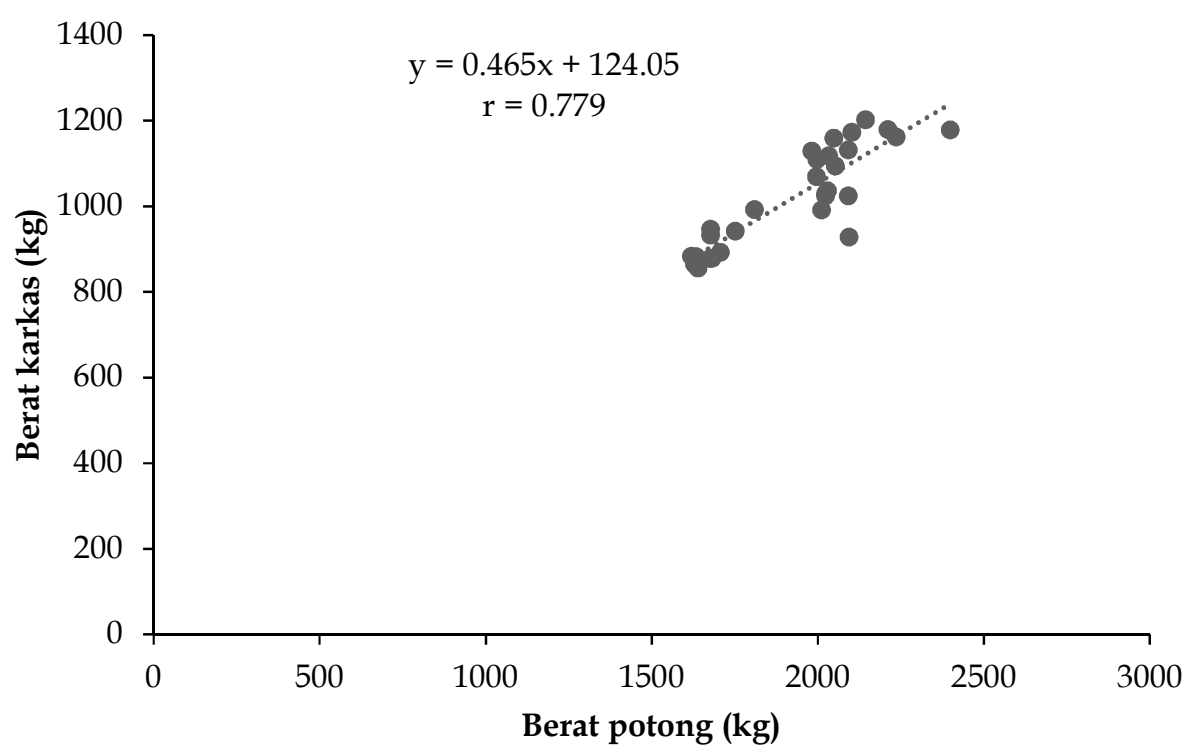

Gambar 1. Diagram pencar hubungan berat potong dan berat karkas pada kelinci jantan lokal $(n=30)$. 


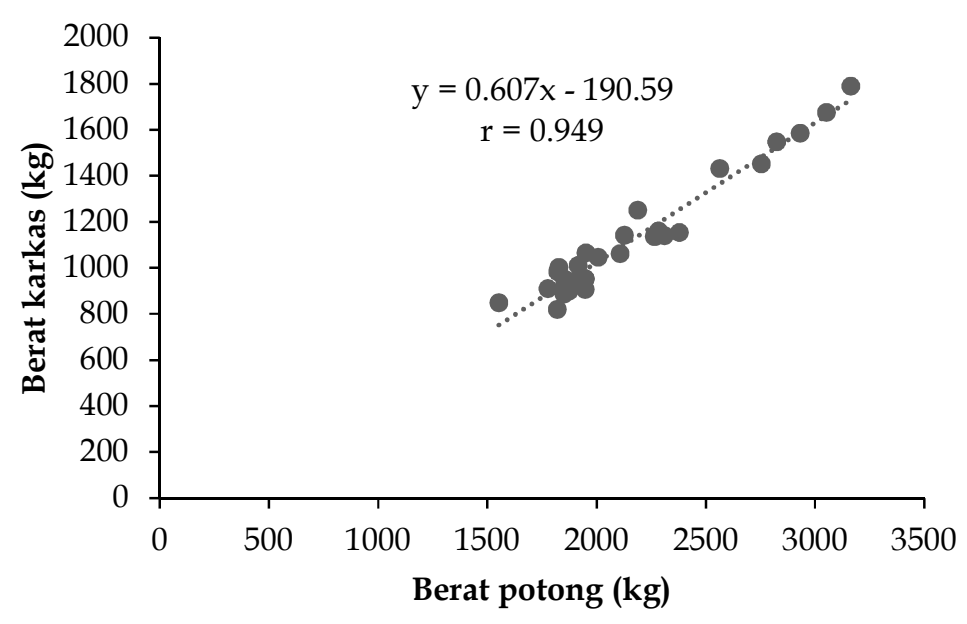

Gambar 2. Diagram pencar hubungan berat potong dan berat karkas pada kelinci jantan New Zealand White $(n=30)$.

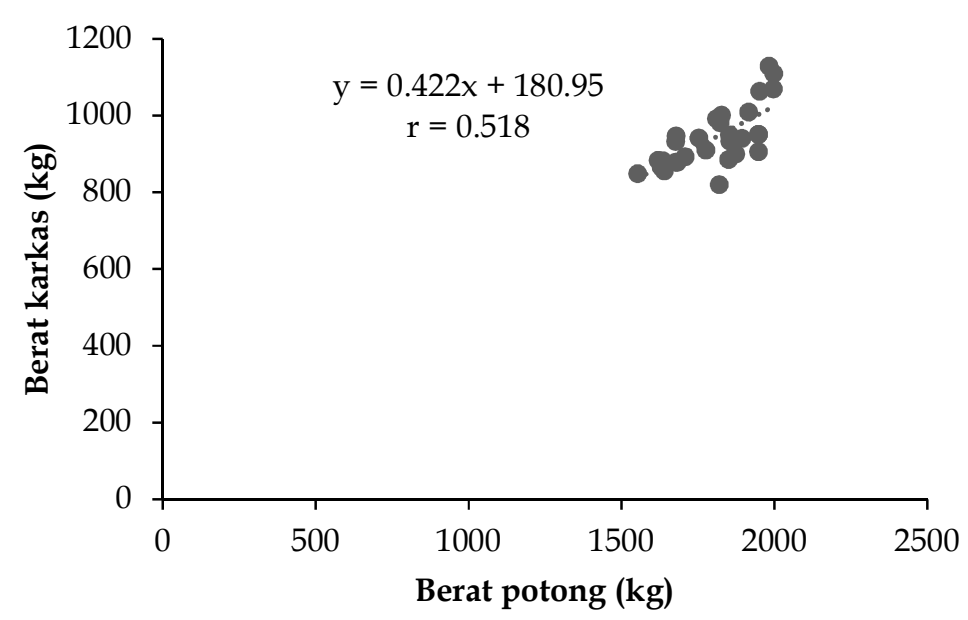

Gambar 3. Diagram pencar hubungan berat potong dan berat karkas pada kelinci jantan dengan kategori potong $<2 \mathrm{~kg}(\mathrm{n}=30)$.

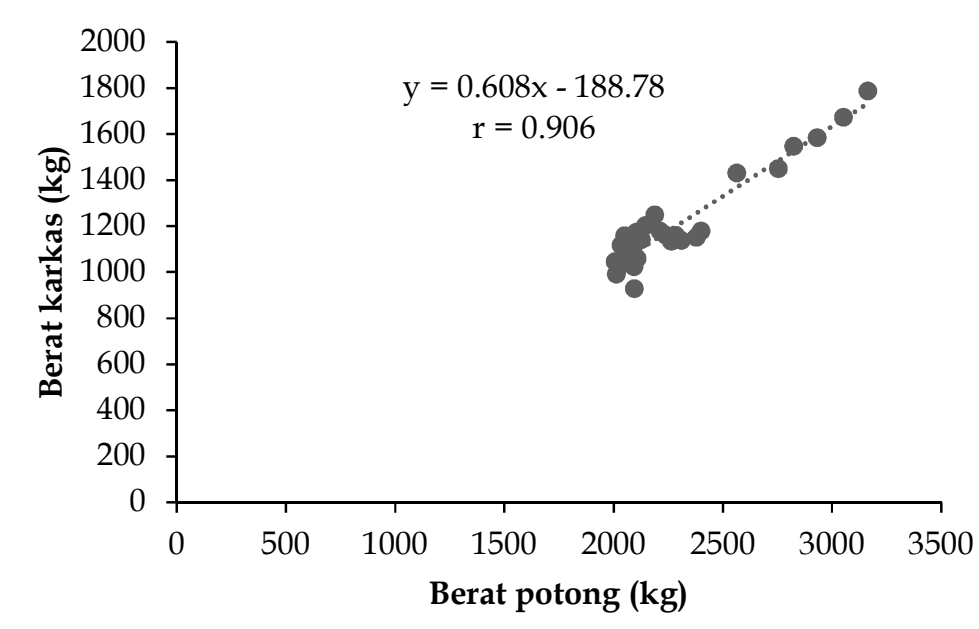

Gambar 4. Diagram pencar hubungan berat potong dan berat karkas pada kelinci jantan dengan kategori potong $>2 \mathrm{~kg}(\mathrm{n}=30)$. 


\section{KESIMPULAN}

Perbedaan bangsa dan berat potong menghasilkan perbedaan pada berat karkas, daging dan tulang kelinci jantan. Akan tetapi, perbedaan bangsa dan berat potong tidak berpengaruh terhadap persentase karkas. Kelinci lokal dengan kategori berat potong <2 $\mathrm{kg}$ dan $>2 \mathrm{~kg}$ menghasilkan persentase karkas dan MBR yang tidak berbeda. Kelinci New Zealand White sebaiknya dipotong pada berat $>2$ $\mathrm{kg}$ karena pada berat potong $<2 \mathrm{~kg}$ menghasilkan rasio MBR yang rendah. Estimasi berat karkas (y) kelinci jantan berdasarkan berat potong $(\mathrm{x})$ dapat ditentukan dengan rumus $\mathrm{y}=$ $0,465 \mathrm{x}+124,05(\mathrm{r}=0,779$; kelinci lokal $)$ dan $\mathrm{y}=$ 0,607x - 190,59 (r=0,949; kelinci New Zealand White).

\section{KONFLIK KEPENTINGAN}

Tidak terdapat konflik kepentingan yang berhubungan dengan penelitian ini.

\section{UCAPAN TERIMA KASIH}

Terima kasih kepada Bapak Waldi, selaku pemilik usaha peternakan dan pemotongan kelinci, atas bantuan materi penelitian. Terima kasih juga kami sampaikan kepada Bapak Gunawan Sulistiyo, S.Pt atas bantuan teknis selama penelitian.

\section{DAFTAR PUSTAKA}

Al-Dobaib, S. N. 2010. Effect of diets on growth, digestibility, carcass and meat quality characteristics of four rabbit breeds. Saudi J. Biol. Sci. 17(1): 83-93.

Belabbas, R., M. D. L. L. Garcia, H. Ainbaziz, N. Benali, A. Berbar, Z. Boumahdi, \& M. J. Argente. 2019. Growth performances, carcass traits, meat quality, and blood metabolic parameters in rabbits of local Algerian population and synthetic line. Vet. World. 12(1): 55-62.

Blasco, A., I. Nagy, \& P. Hernández. 2018. Genetics of growth, carcass and meat quality in rabbits. Meat Sci. 145: 178-185.

Brahmantiyo, B., H. Nuraini, \& D. Rahmadiansyah. 2017. Produktivitas karkas kelinci Hyla,
Hycole dan New Zealand White. Pros. Sem. Nas. Peternakan Vet. 14: 616-626.

Brahmantiyo, B., M. A. Setiawan, \& M. Yamin. 2014. Sifat fisik dan kimia daging kelinci rex dan lokal (Oryctolagus cuniculus). Jurnal Peternakan Indonesia. 16(1): 1-7.

Cullere, M. \& A. D. Zotte. 2018. Rabbit meat production and consumption: State of knowledge and future perspectives. Meat Sci. 143: 137-146.

Haryoko, I. \& T. Warsiti. 2008. Pengaruh jenis kelamin dan bobot potong terhadap karakteristik fisik karkas kelinci New Zealand White. Anim. Prod. 10(2): 85-89.

Hassan, R. A., T. A. Ebeid, A. I. A. El-lateif, \& N. B. Ismail. 2011. Effect of dietary betaine supplementation on growth, carcass and immunity of New Zealand White rabbits under high ambient temperature. Livest. Sci. 135(23): 103-109.

Kementerian Pertanian. 2018. Statistik Peternakan dan Kesehatan Hewan. Direktorat Jenderal Peternakan dan Kesehatan Hewan. Jakarta.

Lazzaroni, C., D. Biagini, \& C. Lussiana. 2009. Different rearing systems for fattening rabbits: Performance and carcass characteristics. Meat Sci. 82(2): 200-204.

Marhaeniyanto, E., S. Rusmiwari, \& S. Susanti. 2015. Pemanfaatan daun kelor untuk meningkatkan produksi ternak kelinci New Zealand White. Buana Sains. 15(2): 119-126.

Mu'tazi, A., C. M. S. Lestari, \& E. Purbowati. 2019. Rasio daging dan tulang karkas kelinci New Zealand White jantan yang diberi ransum dengan penambahan rumput laut (Sargassum sp.). Sem. Nas. Dies Natalis UNS ke 43. 3(1).

Nasr. M. A. F., T. Abd-Elhamid, \& M. A. Hussein. 2017. Growth performance, carcass characteristics, meat quality and muscle amino-acid profile of different rabbits breeds and their crosses. Meat Sci. 134: 150-157.

Priyanti, A. \& Y. C. Raharjo. 2012. Market driving to develop rabbit meat products in Indonesia. Wartazoa. 22(3): 99-106.

Royadi, H. N. \& B. Malik. 2016. Pengaruh pemberian air rebusan daun sirih (Pipper betle linn) dalam air minum terhadap bobot potong dan presentase karkas kelinci lokal. J. Peternakan Nusantara. 2(2): 73-78.

Steel, R. G. D., \& J. H. Torrie. 1960. Principles and procedures of statistics. McGraw. New York. 
Suliani, S., A. Pramono, J. Riyanto, \& S. Prastowo. 2017. Hubungan ukuran-ukuran tubuh terhadap bobot badan sapi Simmental Peranakan Ongole jantan pada berbagai kelompok umur di rumah pemotongan hewan sapi Jagalan Surakarta. Sains Peternak. 15(1): 16-21.

Tůmová, E., Z. Bízková, V. Skřivanová, D. Chodová, M. Martinec, \& Z. Volek. 2014. Comparisons of carcass and meat quality among rabbit breeds of different sizes, and Hybrid rabbits. Livest. Sci. 165: 8-14.
Wibowo, R. Y., J. Riyanto, \& Y. B. P. Subagyo. 2014. Pengaruh penggunaan ampas teh (Camellia sinensis) dalam ransum terhadap produksi karkas kelinci New Zealand White jantan. Biofarmasi. 12(1): 11-17.

Zotte, A. D., K. Szendro, Z. Gerencser, Z. Szendro, M. Cullere, M. Odermatt, I. Odermatt, I. Radnai, \& Z. Matics. 2015. Effect of genotype, housing system and hay supplementation on carcass traits and meat quality of growing rabbits. Meat Sci. 110: 126-134. 